\title{
Cultivar Effects on the Expression of Induced Resistance in Spring Barley
}

Dale R. Walters, Neil D. Havis, Linda Paterson, Jeanette Taylor, and David J. Walsh, Crop and Soil Systems Research Group, Scottish Agricultural College, West Mains Road, Edinburgh EH9 3JG, UK

\begin{abstract}
Walters, D. R., Havis, N. D., Paterson, L., Taylor, J., and Walsh, D. J. 2011. Cultivar effects on the expression of induced resistance in spring barley. Plant Dis. 95:595-600.

The influence of host genotype on the expression of induced resistance was examined in several cultivars of spring barley (Hordeum vulgare). Induced resistance was activated using a combination of elicitors (acibenzolar- $S$-methyl, $\beta$-aminobutyric acid, and cis-jasmone) shown in previous work to induce resistance effectively in barley. The barley cultivars examined were Cellar, Chalice, Decanter, Oxbridge, Tipple, Troon, and Westminster, which differed in their genetic resistance to two major pathogens of barley, Rhynchosporium secalis and Blumeria graminis f. sp. hordei. Controlled-environment studies showed that, although the elicitor combination reduced levels of $R$. secalis in all but one cultivar, the magnitude of the reduction differed among cultivars. Similar results were obtained in field experiments in 2007, 2008, and 2009, although there was inconsistency in cultivar effects between

years, with the elicitor providing disease control in some cultivars in some years and not others. Use of the elicitor combination produced no significant effect on grain yield compared with untreated plants in most cases, although significant increases in grain yield were obtained with the elicitor treatment in two cultivars in 2007 and one cultivar in 2009. Analysis of the defense-related enzyme cinnamyl alcohol dehydrogenase in leaf samples from the field experiment in 2007 showed that activity of the enzyme was already high prior to elicitor application, although activity was increased further in one cultivar following elicitor treatment. It is possible, therefore, that these plants were already induced. Further work is required to confirm this and to determine whether prior induction has any bearing on the variable disease control obtained from elicitors in spring barley.
\end{abstract}

It is now well established that, following infection by a microbial pathogen, plants can develop an enhanced resistance to further infection $(8,15)$. This phenomenon is known as induced resistance and can be split broadly into two major types: systemic acquired resistance (SAR) and induced systemic resistance (ISR). In SAR, plants develop a broad-spectrum systemic resistance to pathogen infection following a localized infection by a necrotizing pathogen or treatment with various agents (e.g., acibenzolar- $S$-methyl [ASM]). SAR is associated with increased levels of salicylic acid (SA) locally and systemically and with the coordinate expression of a specific set of genes encoding pathogenesis-related (PR) proteins (20). Treatment of plants with ASM, a functional analogue of SA, activates the same set of $P R$ genes (24). In contrast, ISR develops as a result of colonization of plant roots by certain strains of plant growth-promoting rhizobacteria (PGPR), and is mediated by a jasmonic acid (JA)- and ethylene (ET)-sensitive signaling pathway (20). Although SAR and ISR are associated with direct activation of defenses, they can also be associated with an ability to recall a previous infection or chemical treatment. This is known as priming and leads to plants responding more quickly and effectively when exposed to subsequent pathogen attack (7).

A wide range of microbes and chemicals (known as elicitors or activators) can induce resistance, including the non-protein amino acid $\beta$-aminobutyric acid (BABA). BABA induces resistance in a cultivar of crop plants, although the signaling involved is complex. Thus, in Arabidopsis, BABA has been shown to function via priming for SA-inducible defenses against Pseudomonas syringae and Botrytis cinerea, and to function via priming of callose deposition, apparently involving abscisic acid (ABA), against Hyaloperonospora parasitica and Alternaria brassicicola $(27,37,38)$.

Cis-jasmone (CJ) is a plant-produced volatile which is emitted following insect damage and is known to activate defenses against

Corresponding author: D. R. Walters, E-mail: dale.walters@sac.ac.uk

Accepted for publication 16 January 2011.

doi:10.1094/PDIS-08-10-0577

(C) 2011 The American Phytopathological Society herbivorous insects $(2,4)$. It is structurally related to JA and methyl-JA (MeJA), both of which are potent activators of plant defense $(6,26)$. However, compared with MeJA, CJ upregulates a unique and more limited set of genes $(2,19)$. As far as we are aware, there is no published evidence that $\mathrm{CJ}$ can activate defenses against plant pathogens, although there is recent evidence that CJ induces resistance against the leaf scald fungus Rhynchosporium secalis, on barley (Hordeum vulgare L.) (D. R. Walters, unpublished results).

As part of a research program examining the potential of induced resistance to control foliar pathogens on barley, we have found that ASM, BABA, and CJ provide better disease control in combination than when used individually (33). There are some reports that the expression of induced resistance can be influenced by genotype $(28,35)$, although no such information exists for many crops, including spring barley. The objective of this work was to examine the influence of cultivar on the efficacy of resistance, induced using the elicitor combination ASM+BABA+CJ.

\section{Materials and Methods}

Plant materials. The cultivars of spring barley chosen for study, together with their previously obtained resistance ratings (RRs) for $R$. secalis and powdery mildew (caused by Blumeria graminis $\mathrm{f}$. sp. hordei), are shown in Table 1 . The only cultivar with effective resistance to $R$. secalis is 'Westminster', which carries the resistance gene BRR5. The cultivars chosen possessed moderate to high levels of resistance to powdery mildew, based on the mlo gene (Table 1). The cultivars in this study were chosen primarily for their diversity of levels of resistance to $R$. secalis.

Elicitor treatments. The elicitors used in these experiments were ASM (as Bion; applied at $1 \mathrm{mM}$ ), BABA (applied at $1 \mathrm{mM}$ ), and CJ (applied at $0.625 \mathrm{~g} /$ liter). These rates of application were determined in preliminary field trials to provide optimum control of $R$. secalis. Bion was a gift from Syngenta, Basel, Switzerland, and BABA and CJ were purchased from Sigma-Aldrich, Poole, Dorset, UK.

Controlled-environment experiment. Barley seed ('Cellar') were sown in pots in Fisons Levington compost and grown in a walk-in growth room at $18^{\circ} \mathrm{C}$ with a 16 -h photoperiod $(190 \mu \mathrm{mol}$ $\mathrm{m}^{-2} \mathrm{~s}^{-1}$ provided by $400-\mathrm{W}$ mercury vapor lamps). Plants were used for experiments when the sixth leaf was fully formed and the 
seventh leaf emerging. Leaves one to four were sprayed with elicitors using a hand-held sprayer. Two days later, plants were inoculated with the leaf scald pathogen $R$. secalis by spraying with a suspension of spores $\left(1 \times 10^{5}\right.$ spores $\left./ \mathrm{ml}\right)$ in distilled water containing $0.01 \%$ Tween 20 . Inoculated plants were then covered with plastic bags for $48 \mathrm{~h}$ (the first $24 \mathrm{~h}$ in the dark) and kept at $16^{\circ} \mathrm{C}$ to provide the conditions necessary for spore germination and early fungal development. Thereafter, the temperature of the growth room was increased to $18^{\circ} \mathrm{C}$ for the remainder of the experiment. Infection intensity was assessed 21 days after inoculation by determining the percent leaf area exhibiting symptoms. The controlledenvironment experiment to examine the effects on spring barley cultivars of $R$. secalis infection was repeated twice, with similar results. In these experiments, values for disease assessment are the means of 10 replicates.

Field experiments. Field experiments were conducted in 2007 at Tibbermore, Perth, Scotland, UK, and in 2008 and 2009 at Drumalbin, Lanark, Scotland, UK. Four spring barley cultivars (Cellar, 'Chalice', 'Decanter,' and Westminster in 2007 and 2008 and Cellar, Decanter, 'Tipple', and Westminster in 2009) were sown in a randomized block design at a seed rate of 360 seeds $\mathrm{m}^{-2}$ and an individual plot size of 10 by $2 \mathrm{~m}$. Three replicate plots were planted per treatment. Plots received standard fertilizer and herbicide regimes.

The field experiments compared the effects of the elicitor combination with standard fungicide treatments used to control foliar pathogens of spring barley in Scotland. Spray dates for treatments were based on plant growth stage as described by Zadoks et al. (36) and were applied with a knapsack sprayer using an equivalent spray volume of 200 liters $\mathrm{ha}^{-1}$. The elicitor combination was applied at GS24 and GS31 and the fungicide treatments at GS31 and GS39. These spray timings were found in initial field experiments to provide best disease control in spring barley. The fungicide treatment used at GS31 was a mixture of prothioconazole (Proline; Bayer Crop Science; $250 \mathrm{~g} \mathrm{liter}^{-1}$ ) used at $0.4 \times$ the manufacturer's recommended rate, and cyprodinil and picoxystrobin (Acanto; Du Pont; $30.8 \%$ [wt/wt]) used at $0.5 \times$ the manufacturer's recommended rate. At GS39, prothioconazole was used at $0.4 \times$ the recommended rate, plus chlorothalonil (Bravo 500; Syngenta; 500 $\mathrm{g} \mathrm{liter}^{-1}$ ) at the full recommended rate. Control plots (one plot per cultivar per block) received no elicitor or fungicide treatment. Experimental plots were not artificially inoculated but relied on natural inoculum.

Disease symptoms (percent leaf area diseased) and percent green leaf area (\%GLA) were assessed on the upper four leaf layers of plants in each plot at spray dates (GS24, GS31, and GS39) and at 14-day intervals after the final spray at GS39. Symptoms of infection by $B$. graminis $\mathrm{f}$. sp. hordei and $R$. secalis were readily discriminated on all leaves examined and, therefore, percent diseased leaf area was assessed separately for the two pathogens. Ten plants from each plot, chosen at random, were used for assessments. Ar- eas under the disease progress curve (AUDPC) were calculated using the formula $\Sigma\left(y_{\mathrm{i}}+y_{(i+1)} / 2 \times\left(t_{(i+1)}-t_{i}\right)\right.$, where $y_{i}$ is the disease rating at time $t_{i}$.

Plots were harvested at normal harvest time and yields expressed as tons per hectare at $85 \%$ dry-matter content. In brief, plots were harvested with a research combine and all grain from individual plots was collected, weighed, and recorded (in kilograms per plot). A subsample of the harvested grain was used to measure moisture content and 1,000-grain weight. The moisture content of the subsample was used to standardize the results to $85 \%$ dry matter.

Enzyme assay. Leaves from plants in the field experiments conducted in 2007 were harvested 7 days after treatment application for plants treated at GS24 and 8 days after treatment application for plants treated at GS31 and GS39. The leaves chosen for analysis were not the same leaves used for disease assessments. At each GS, the uppermost fully formed leaf was harvested from 10 plants per plot. Leaves were frozen immediately in liquid nitrogen for subsequent enzyme analysis. The activity of the defense-related enzyme cinnamyl alcohol dehydrogenase (CAD; EC 1.1.1.195) was determined using a spectrophotometric assay as described by Boyle and Walters (3), scaled down for use with a microtiter plate.

Statistical analysis. All data were subjected to analysis of variance (ANOVA) using the GenStat Release 11.1 statistical program. Percent diseased leaf area values from glasshouse experiments and \%GLA data from field experiments were not normally distributed and, therefore, were log-transformed prior to analysis. Comparison of treatment means was performed using Fisher's protected least significant difference test.

\section{Results}

Controlled-environment studies. In five of the cultivars examined, application of the elicitor combination led to significant $(P<$ 0.01 ) reductions in $R$. secalis disease symptoms (Fig. 1). On Cellar (RR4; Table 1), this reduction was $67 \%$ whereas, on Chalice (RR5), the reduction was $32 \%$. The more resistant 'Oxbridge' (RR7) exhibited a reduction of $60 \%$ whereas, in the most resistant cultivar examined, Westminster (RR8), there were no visible signs of infection, although visible disease levels in control plants were low (Fig. 1). 'Troon' (RR4) was the only cultivar where the elicitor combination had no effect on $R$. secalis symptoms.

Field studies, 2007. Levels of $R$. secalis and powdery mildew were light or moderate in 2007. The elicitor combination was effective in reducing $R$. secalis AUDPC in Chalice and Decanter (Fig. 2A). Here, disease control was not significantly different from that obtained using the fungicide treatment. In contrast, the elicitor combination had no significant effect on $R$. secalis AUDPC in the cultivars Cellar and Westminster, although the fungicide produced significant reductions $(P<0.05)$ in both cultivars (Fig. $2 \mathrm{~A})$. For powdery mildew, the situation was completely different. Here, the elicitor treatment had no significant effect on mildew AUDPC on any of the four cultivars (Fig. 2B). In fact, the fungi-

Table 1. Cultivars of spring barley chosen for induced resistance study, their AFP numbers, ratings for resistance to Rhynchosporium secalis and Blumeria graminis f. sp. hordei, and resistance genes for B. graminis f. sp. horde ${ }^{\text {a }}$

\begin{tabular}{llccc}
\hline & & \multicolumn{2}{c}{ Resistance rating $^{\mathbf{b}}$} & \\
\cline { 3 - 4 } Cultivar $^{\mathbf{c}}$ & AFP & R. secalis & B. graminis f. sp. hordei & Resistance gene \\
\hline Cellar & 1574 & 4 & 9 & mlo \\
Chalice & 1354 & 4 & 9 & mlo11 \\
Decanter & 1411 & 6 & 9 & mlo11 \\
Oxbridge & 1940 & 7 & 7 & mlo \\
Tipple & 1966 & 4 & 8 & mlo \\
Troon & 1755 & 4 & 9 & mlo \\
Westminster & 1939 & 8 & 9 & mlo \\
\hline
\end{tabular}

${ }^{a}$ AFP number = application for protection number (a unique number issued to all U.K. barley cultivars during registration). Genes for resistance to $R$. secalis are not known except for Westminster, which possesses BRR5.

${ }^{\mathrm{b}}$ Resistance ratings: 1 = poor resistance to 9 = good resistance; ratings obtained from the U.K. Home-Grown Cereals Authority (HGCA) recommended lists (HGCA, 2009).

${ }^{c}$ Used in controlled environment experiments: Cellar, Chalice, Decanter, Oxbridge, Troon, and Westminster. Used in field trials in 2007 and 2008 : Cellar, Chalice, Decanter, and Westminster. Used in field trials in 2009: Cellar, Decanter, Tipple, and Westminster. 
cide treatment reduced mildew significantly on Cellar and Westminster but had no significant effect on Chalice and Decanter (Fig. 2B). Treatment with the elicitor combination increased \%GLA significantly $(P<0.05)$ in Cellar, Chalice, and Westminster but not in Decanter (Fig. 2C), whereas grain yield was only increased significantly $(P<0.05)$ in Chalice and Westminster treated with elicitor (Fig. 2D). Interestingly, the fungicide treatment produced no significant effect on grain yield in any of the cultivars.

CAD activity was determined in leaf samples collected at GS24, GS31, and GS39. However, because no differences in enzyme activity were detected in samples from GS31 and GS39, only the data from GS24 are presented. CAD activity was high in untreated plots (Fig. 3). Despite the variability, CAD activity was increased further following elicitor treatment in Chalice $(P<0.05)$ but not in the other cultivars (Fig. 3). Two-way ANOVA of the CAD activity data from this field study revealed a significant interaction between variety and treatment $(\mathrm{F}$ pr. $<0.001)$.

Field studies, 2008. Very low levels of $R$. secalis were obtained in the field experiments in 2008 and, therefore, results are only

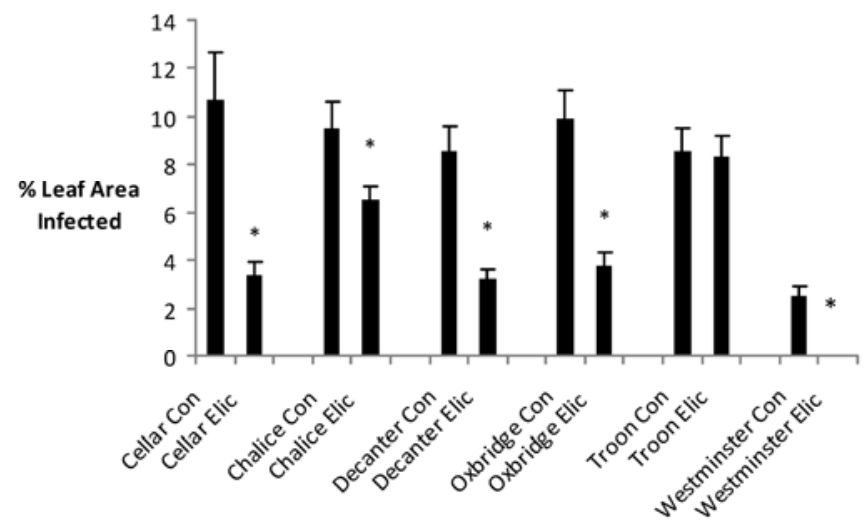

Fig. 1. Effect of the elicitor combination acibenzolar-S-methyl (ASM), $\beta$-aminobutyric acid (BABA), and cis-jasmone (CJ) on infection of six cultivars of spring barley by Rhynchosporium secalis under controlled-environment conditions. Con = untreated control; Elic $=$ treated with the elicitor combination. Significant differences compared with the respective controls are shown as * $(P \leq 0.01)$. shown for powdery mildew. The elicitor combination reduced mildew AUDPC significantly $(P<0.05)$ in Chalice and Decanter but not in the other two cultivars (Fig. 4A). Indeed, in Chalice, the elicitor treatment out-performed the fungicide treatment. In Chalice, Decanter, and Westminster treated with elicitor or with fungicide, \%GLA was increased significantly $(P<0.05)$ but was actually decreased significantly by the elicitor combination on Cellar (Fig. 4B). No significant effects on grain yield were obtained for any cultivar following any of the treatments (Fig. 4C).

Field studies, 2009. Levels of powdery mildew were very low in the field experiments in 2009 and results are only shown for $R$. secalis. Chalice was unavailable and was replaced by Tipple (RR4). The elicitor combination reduced $R$. secalis significantly ( $P$ $<0.05$ ) in Cellar, Decanter, and Westminster but not in Tipple (Fig. 5A). The fungicide treatment reduced $R$. secalis significantly $(P<$ $0.05)$ in all cultivars but was only superior to the elicitor treatment in Cellar and Tipple (Fig. 5A). Both the elicitor and fungicide treatments increased \%GLA significantly $(P<0.05)$ in Cellar and Tipple but had no significant effect on the other two cultivars (Fig. 5B). The elicitor combination increased grain yield significantly in Cellar $(P<0.05)$ but not in the other cultivars. The fungicide treatment increased grain yield significantly $(P<0.05)$ in Cellar, Tipple, and Westminster (Fig. 5C).

\section{Discussion}

This study provides clear evidence of the influence of cultivar on the efficacy of induced resistance in spring barley. Under controlled conditions, the elicitor combination reduced the severity of $R$. secalis on most cultivars, although it had no effect on Troon. On responsive cultivars, the magnitude of disease control achieved ranged from 32 to $67 \%$ and appeared to show no relationship to the RR of the cultivar. Similar effects were observed in the field experiments. Under field conditions, severity of the two pathogens varied between years. Levels of $R$. secalis were light to moderate in 2007, very low in 2008, and moderate to high in 2009. With powdery mildew, severity was light in 2007 , light to moderate in 2008, and too low to assess in 2009. Nevertheless, the degree of disease control obtained with the elicitor combination under field conditions was clearly dependent on cultivar. However, in the field, the degree of disease control was dependent not just on cultivar but
A
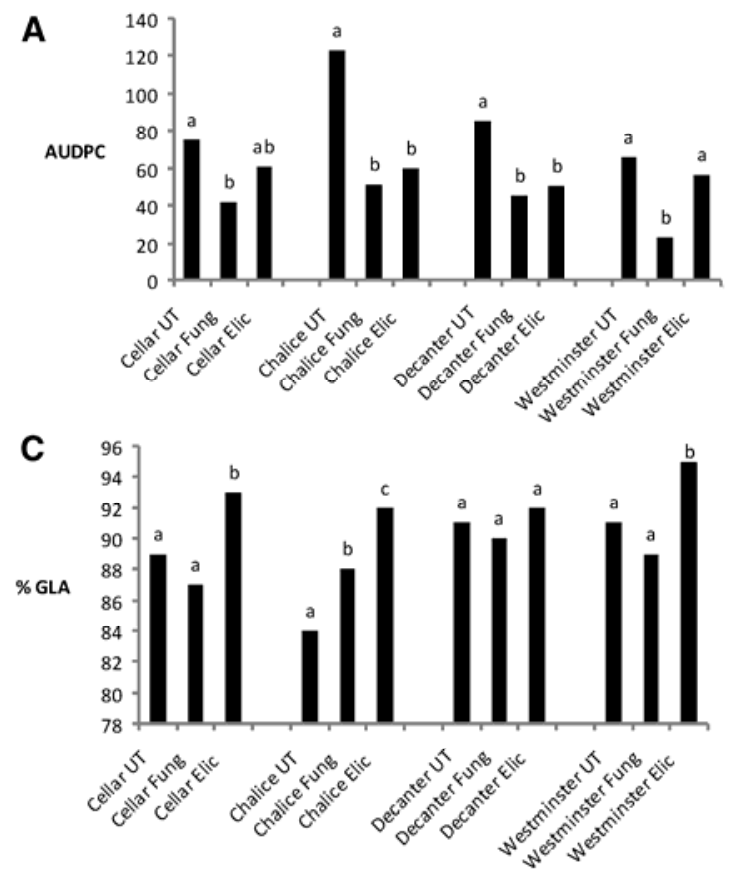

B
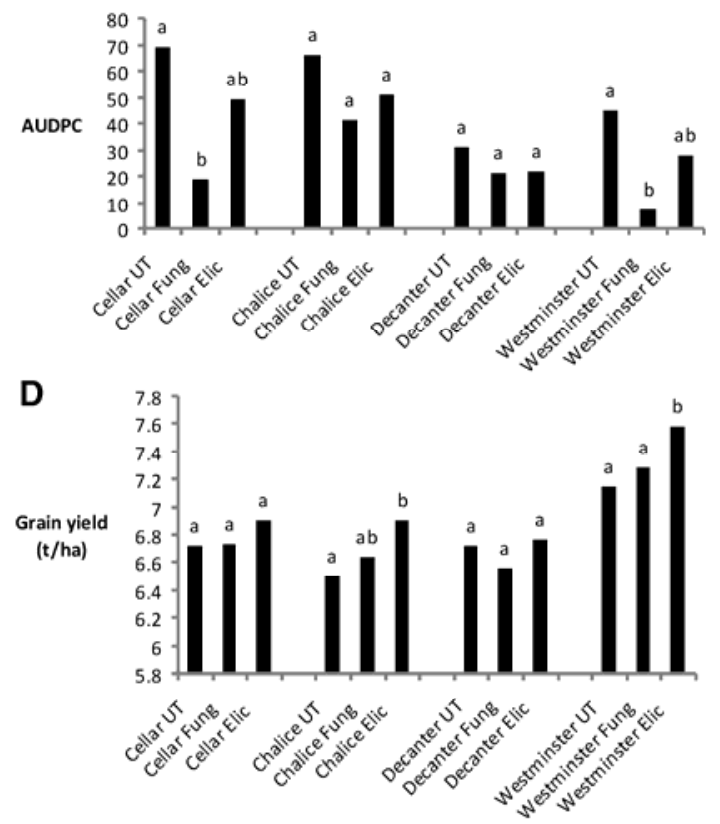

Fig. 2. Field performance of the elicitor combination acibenzolar-S-methyl (ASM), $\beta$-aminobutyric acid (BABA), and cis-jasmone (CJ) on four cultivars of spring barley in 2007. A, Rhynchosporium secalis areas under the disease progress curve (AUDPC); B, powdery mildew AUDPC; C, percent green leaf area (\%GLA); D, grain yield. UT = untreated; Fung = standard fungicide treatment; Elic $=$ treated with the elicitor combination. For all cultivars, bars with different letters are significantly different at $P \leq 0.05$ (Fisher's least significant difference). 
also on year. For example, the elicitor combination provided no control of R. secalis on Cellar and Westminster in 2007, when levels of both pathogens were light, but provided significant control of $R$. secalis in 2009, when levels of this pathogen were moderate. Similarly, elicitors provided no control of powdery mildew on Chalice in 2007 but did so in 2008, a year in which powdery mildew severity was moderate. In contrast, significant control of $R$. secalis was obtained on Decanter in both 2007 and 2009, despite the difference in pathogen levels in the two years.

These results highlight a major consideration when using induced resistance under field conditions: inconsistency, a phenomenon that has been widely reported with use of elicitors on field crops, especially cereals (22). The fact that the field trials in 2008 and 2009 were conducted at a location different from that used in 2007 undoubtedly added to the inconsistency of the results. Interestingly, the disease control data presented in this study suggest a possible link between the efficacy of induced resistance and pathogen pressure, with the elicitor combination providing better disease control in years when levels of $R$. secalis and B. graminis f. sp. horde $i$ were moderate to high. This contrasts with work on tomato, which showed that ASM was more effective against Ralstonia solanacearum when pathogen inoculum pressure was low (21). Nevertheless, this observation in spring barley deserves further investigation because, if it is supported by further experimental evidence, it would influence the practical use of elicitors in this crop.

Host genotype has been shown previously to influence the expression of induced resistance, although the relationship with the genetic resistance of the cultivars used in those studies was dependent on plant species (31). Thus, the expression of resistance in cucumber to the powdery mildew fungus Sphaerotheca fuligenea, induced by 2,6-dichloroisonicotinic acid (INA) was found to be cultivar dependent, with the highest levels of resistance expressed in cultivars with partial resistance to the pathogen (12). In soybean, reductions in levels of Sclerotinia sclerotiorum, induced by treatment with ASM or INA, were greatest in susceptible cultivars (5). In contrast, in tobacco, ASM only provided control of blue mold (Peronospora hyocyami f. sp. tabacina) on resistant, not susceptible, cultivars (18). In more recent work using BABA to induce resistance, tomato genotypes were shown to vary significantly in inducibility of resistance to Phytophthora infestans (25). In that study, the level of induction was not always related to the resistance level of the tomato accessions and, indeed, was influenced significantly by pathogen isolate (25).

In the present study on spring barley, there was little correlation between the efficacy of the elicitor combination and the RR of the cultivar, although we have no information on the isolates of Rhynchosporium secalis and B. graminis f. sp. hordei encountered by the cultivars in the field. Nevertheless, it is possible that the lack of

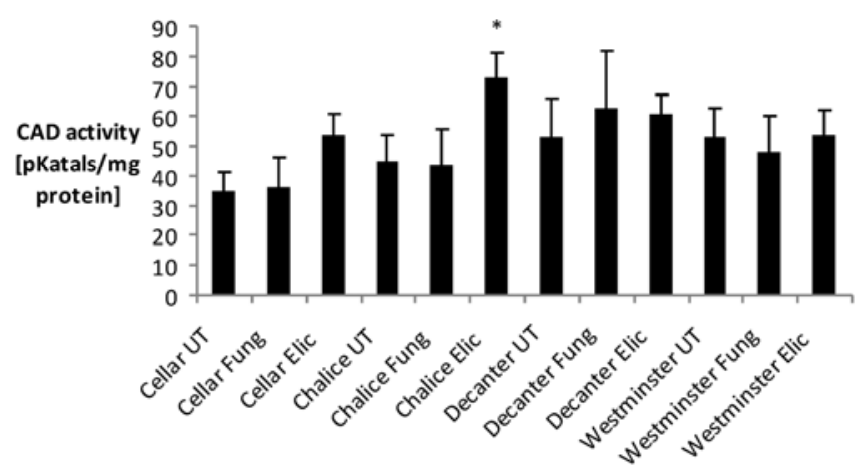

Fig. 3. Activity of cinnamyl alcohol dehydrogenase (CAD) in leaves of four barley cultivars treated with the elicitor combination acibenzolar-S-methyl (ASM), $\beta$ aminobutyric acid (BABA), and cis-jasmone (CJ) in the 2007 field experiment. UT = untreated; Fung = standard fungicide treatment; Elic $=$ treated with the elicitor combination. Significant differences compared with the respective untreated control are shown as * $(P \leq 0.05)$. correlation between efficacy of induced resistance in the barley cultivars and their RRs could reflect differences in defense mechanisms activated by the elicitor combination and differences in virulence mechanisms operating in different pathogen isolates. Indeed, virulence mechanisms of pathogens can also be variable. For example, different resistance suppressors from different races of $P$. infestans affected defense responses of potato in a different way (1). Differing virulence mechanisms among isolates of B. graminis f. sp. hordei could also be responsible for the observation that, despite their high RR to powdery mildew, most of the untreated cultivars exhibited appreciable symptoms of infection. However, because levels of powdery mildew were higher in 2008 than in 2007 and 2009, and untreated Chalice and Decanter exhibited the greatest AUDPCs for powdery mildew in 2008, it is possible that there was a breakdown in $m l o 11$ resistance.

There have been concerns that activation of induced resistance could result in a cost to the plant, with energy and resources diverted away from growth and development toward defense $(10,30)$. Indeed, several workers have reported reductions in crop yield
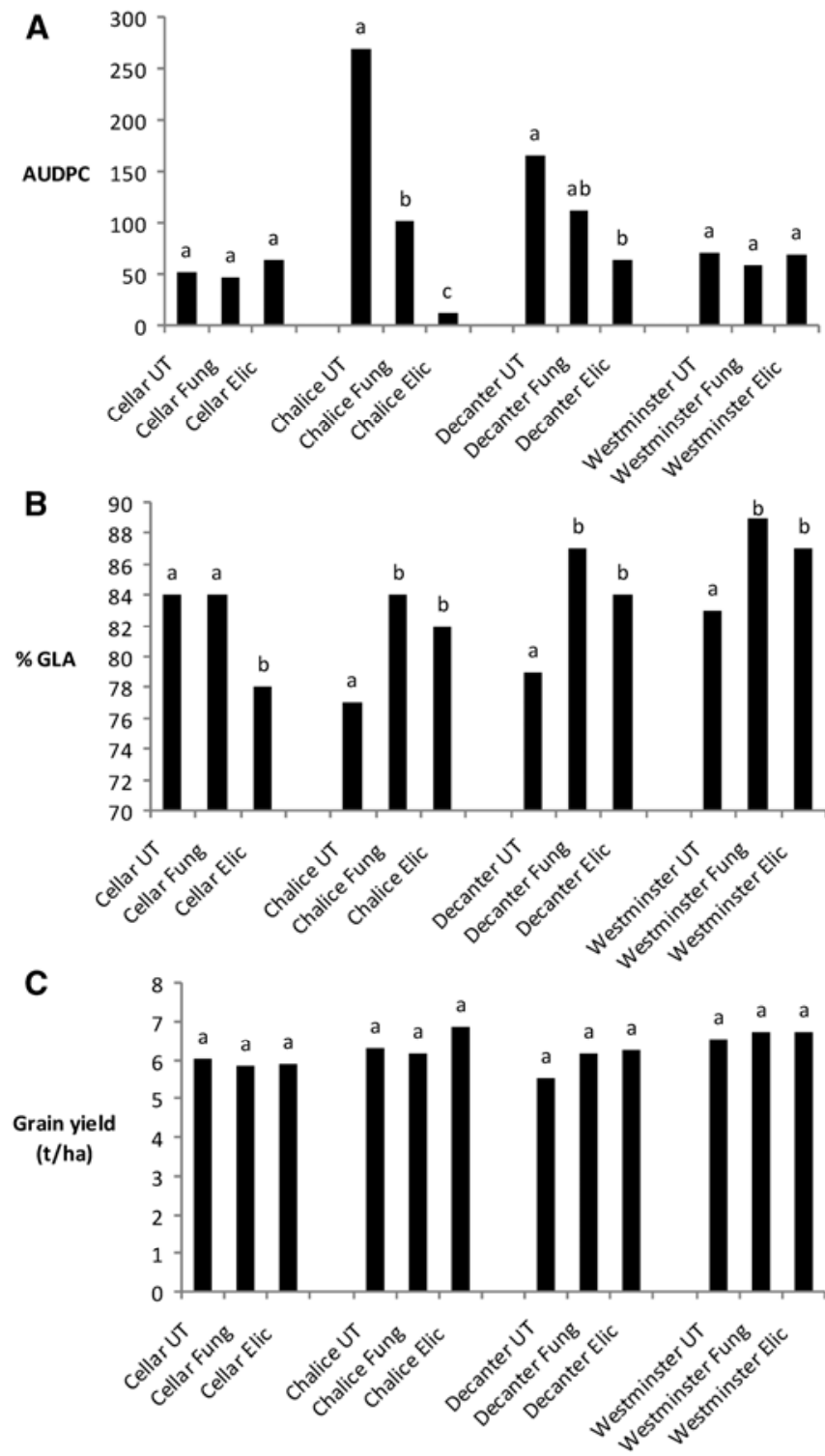

Fig. 4. Field performance of the elicitor combination acibenzolar-S-methyl (ASM), $\beta$-aminobutyric acid (BABA), and cis-jasmone (CJ) on four cultivars of spring barley in 2008. A, Powdery mildew areas under the disease progress curve (AUDPC); B, percent green leaf area $(\% \mathrm{GLA}) ; \mathbf{C}$, grain yield. UT = untreated; Fung = standard fungicide treatment; Elic = treated with the elicitor combination. For all cultivars, bars with different letters are significantly different at $P \leq 0.05$ (Fisher's least significant difference). 
following use of ASM in the field although, in many cases, these reductions were not statistically significant $(16,22,23)$. However, these studies were not designed to quantify the costs of induced resistance, because they were conducted in the presence of pathogen challenge. Interestingly, when appropriately designed studies were performed with ASM, one study reported that costs were incurred (9), while the other could find no evidence for costs (14). Subsequent work has shown that priming is less costly to the plant compared with direct induction of resistance $(27,29,32,34)$. In the present work, although elicitor use had no significant effect on grain yield in most cultivars over the 3 years of field studies, significant yield increases were obtained on Chalice and Westminster in 2007 and in Cellar in 2009. When \%GLA was compared in the different cultivars over the 3 years, there was no consistent correlation between \%GLA and grain yield. Indeed, in several cases, a significant increase in \%GLA was associated with no significant effect on grain yield. The physiological basis for these responses is not known but warrants further examination.

One of the reasons suggested to account for the relatively low levels of disease control provided by elicitors, especially in cereals,
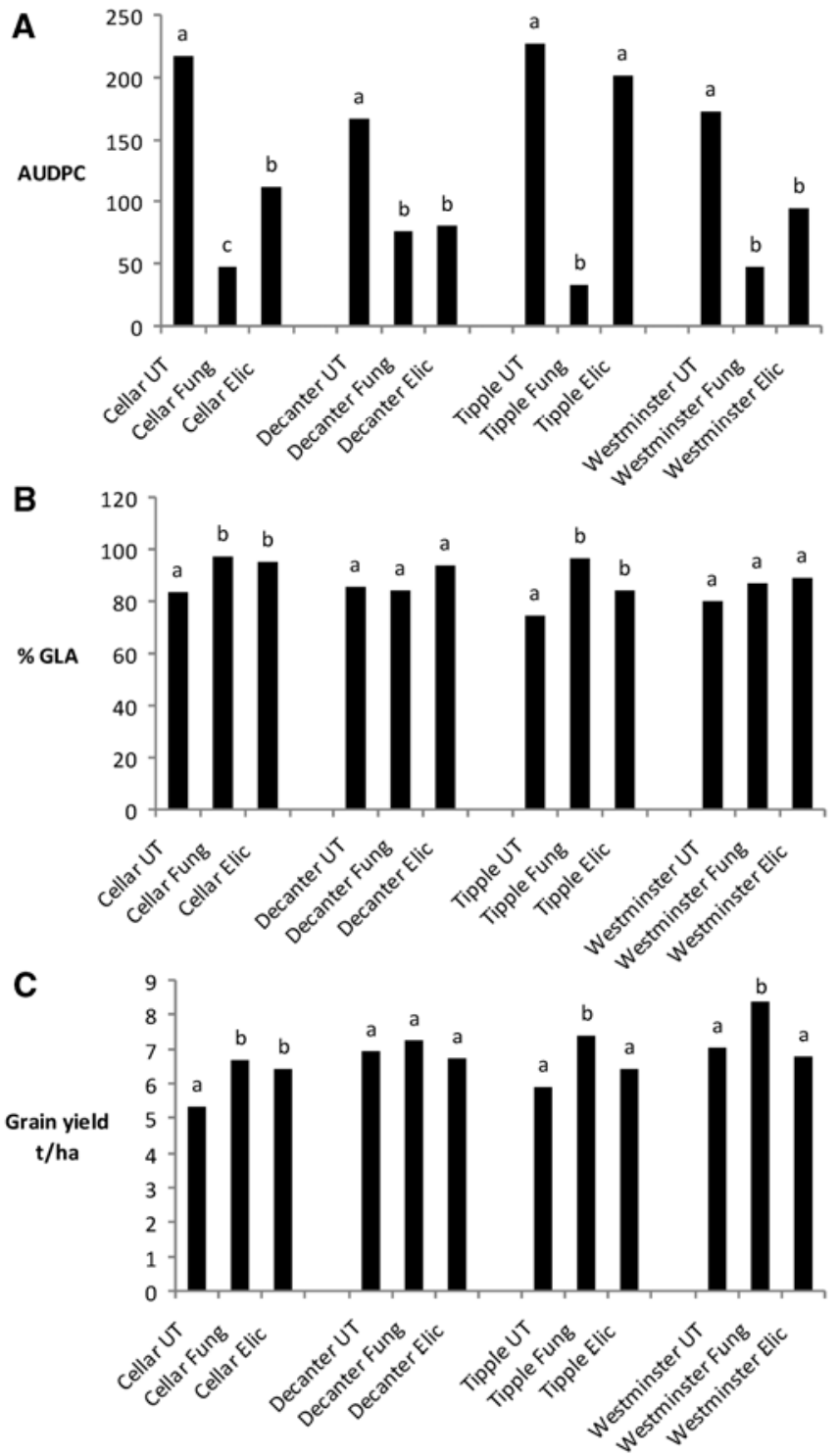

Fig. 5. Field performance of the elicitor combination acibenzolar-S-methyl (ASM), $\beta$-aminobutyric acid (BABA), and cis-jasmone (CJ) on four cultivars of spring barley in 2009. A, Rhynchosporium secalis areas under the disease progress curve (AUDPC); B, percent green leaf area (\%GLA); C, grain yield. UT = untreated; Fung = standard fungicide treatment; Elic = treated with the elicitor combination. For all cultivars, bars with different letters are significantly different at $P \leq 0.05$ (Fisher's least significant difference). is the possibility that, under field conditions, plants are likely to be already induced (28). The question posed is that, if plants are already partially induced, to what extent can their resistance be further induced? In the present study, CAD activity was chosen as a biochemical measure of induced resistance because it was shown in initial work to be primed for enhanced activity in glasshousegrown plants treated with the elicitor combination (data not shown). Measurement of CAD activity in leaves taken from plants in the field study in 2007 showed that enzyme activity was already high in untreated plants, prior to application of elicitors. Similar results have been reported for expression of defense-related genes in field-grown wheat and tomato $(11,17)$. In the present work, despite the variability usually experienced with biochemical measurements under field conditions, CAD activity was increased significantly in Chalice compared with untreated plants following elicitor application. However, because there was a significant interaction between variety and treatment, these data should be interpreted with caution. Therefore, although the data suggest that plants in the field are likely to express defenses prior to treatment, they provide no firm evidence that defenses can be further induced by elicitor treatment. Moreover, increases in CAD activity in this field experiment were not always associated with reductions in AUDPC, perhaps reflecting the fact that effective pathogen resistance will be based on activation of multiple mechanisms (35). However, for induced resistance to be effective, increased defenses need to be translated into disease control and, as we have seen above, the disease control obtained in barley from application of elicitors can vary with cultivar and year.

\section{Acknowledgments}

This work was funded by the Scottish Government Rural and Environment Research and Analysis Directorate (Work Package 1.4-barley pathology). We thank D. McKenzie of Syngenta, Basle, Switzerland, for the gift of Bion.

\section{Literature Cited}

1. Andreu, A., Tonón, C, van Damme, M., and Daleo, G. 1998. Effects of glucans from different races of Phytophthora infestans on defense relations in potato tubers. Eur. J. Plant Pathol. 104:777-783.

2. Birkett, M. A., Campbell, C. A., Chamberlain, K., Guerrieri, E., Hick, A. J. Martin J. L, Matthes, M., Napier, J. A., Pettersson, J., Pickett, J. A., Poppy, G. M., Pow, E. M., Pye, B. J., Smart, L. E., Wadhams, G. H., and Woodcock, G. M. 2000. New roles for cis-jasmone as an insect semiochemical and in plant defense. Proc. Natl. Acad. Sci. USA 97:9329-9334.

3. Boyle, C., and Walters, D. R. 2006. Saccharin-induced resistance to powdery mildew in barley: effects on growth and phenylpropanoid metabolism. Plant Pathol. 55:82-91.

4. Bruce, T. J. A., Pickett, J. A., and Smart, L. E. 2003. cis-jasmone switches on plant defence against insects. Pestic. Outlook 14:96-98.

5. Dann, E., Diers, B., Byrum, J., and Hammerschmidt, R. 1998. Effect of treating soybean with 2,6-dichloroisonicotinic acid (INA) and benzothiadiazole (BTH) on seed yields and the level of disease caused by Sclerotinia sclerotiorum in field and glasshouse studies. Eur. J. Plant Pathol. 104:271278.

6. Farmer, E. E., and Ryan, C. A. 1990. Interplant communication: airborne methyl jasmonate induces synthesis of proteinase inhibitors in plant leaves. Proc. Natl. Acad. Sci. USA 87:7713-7716.

7. Goellner, K., and Conrath, U. 2008. Priming: it's all the world to induced resistance. Eur. J. Plant Pathol. 121:233-242.

8. Hammerschmidt, R. 2007. Introduction: definitions and some history. Pages 1-8 in: Induced Resistance for Plant Disease Control: A Sustainable Approach to Crop Protection. D. Walters, A. Newton, and G. Lyon, eds. Blackwell Publishing, Oxford.

9. Heil, M., Hilpert, A., Kaiser, W., and Linsenmair, K. E. 2000. Reduced growth and seed set following chemical induction of pathogen defence: does systemic acquired resistance (SAR) incur allocation costs? J. Ecol. 88:645-654.

10. Heil, M., and Walters, D. R. 2009. Ecological consequences of plant defence signalling. Adv. Bot. Res. 51:667-716.

11. Herman, M. A. B., Restrepo, S., and Smart, C. D. 2007. Defense gene expression patterns of three SAR-induced tomato cultivars in the field. Physiol. Mol. Plant Pathol. 71:192-200.

12. Hijwegen, T., and Verhaar, M. A. 1994. Effect of cucumber genotype on the induction of resistance to powdery mildew, Sphaerotheca fuligenea, by 2,6dichloroisonicotinic acid. Plant Pathol. 44:756-762.

13. Home-Grown Cereals Authority. 2009. HGCA Recommended List Spring Barley 2009. HGCA, UK

14. Iriti, M., and Faoro, F. 2003. Does benzothiadiazole-induced resistance increase fitness cost in bean? J. Plant Pathol. 85S:265-270. 
15. Kuć, J. 1982. Induced immunity to plant diseases. BioScience 32:854-860.

16. Louws, F. J., Wilson, M., Campbell, H. L., Cuppels, D. A., Jones, J. B., Shoemaker, P. B., Sahin, F., and Miller, S. A. 2001. Field control of bacterial spot and bacterial speck of tomato using a plant activator. Plant Dis. 85:481-488.

17. Pasquer, F., Isidore, E., Zarn, J., and Keller, B. 2005. Specific patterns of changes in Wheat gene expression after treatment with three antifungal compounds. Plant Mol. Biol. 57:693-707.

18. Perez, L., Rodriguez, M. E., Rodriguez, F., and Roson, C. 2003. Efficacy of acibenzolar-S-methyl, an inducer of systemic acquired resistance, against tobacco blue mould caused by Peronospora hyocyami f. sp. tabacina. Crop Prot. 22:405-413.

19. Pickett, J. A., Birkett, M. A., Moraes, M. C. B., Bruce, T. J. A., Chamberlain, K., Gordon-Weeks, R., Matthes, M.C., Napier, J.A., Smart, L. E., Wadhams, G. H., Woodcock, G. M. 2007. cis-jasmone as an allelopathic agent in inducing plant defence. Allelopath. J. 19:109-117.

20. Pieterse, C. M. J., and Van Loon, L. C. 2007. Signalling cascades involved in induced resistance. Pages 65-88 in: Induced Resistance for Plant Disease Control: A Sustainable Approach to Crop Protection. D. Walters, A. Newton, and G. Lyon, eds. Blackwell Publishing, Oxford.

21. Pradhanang, P. M., Ji, P., Momol, M. T., Olson, S. M., Mayfield, J. L., and Jones, J. B. 2005. Application of acibenzolar-S-methyl enhances host resistance in tomato against Ralstonia solanacearum. Plant Dis. 89:989-993.

22. Reglinski, T., and Walters, D. 2009. Induced resistance for plant disease control. Pages 62-92 in: Disease Control in Crops: Biological and Environmentally Friendly Approaches. D. Walters, ed. Wiley-Blackwell, Oxford.

23. Romero, A. M., Kousik, C. S., and Ritchie, D. F. 2001. Resistance to bacterial spot in bell pepper induced by acibenzolar-S-methyl. Plant Dis. 85:189-194.

24. Ryals, J. A., Neuenschwander, U. H., Willits, M. G., Molina, A., Steiner, H.Y., and Hunt, M. D. 1996. Systemic acquired resistance. Plant Cell 8:18081819.

25. Sharma, K., Butz, A. F., and Finckh, M. R. 2010. Effects of host and pathogen genotypes on inducibility of resistance in tomato (Solanum lycopersicum) to Phytophthora infestans. Plant Pathol. 59:1062-1071.

26. Thaler, J. S., Stout, M. J., Karban, R., and Duffey, S. S. 1996. Exogenous jasmonates simulate insect wounding in tomato plants (Lycopersicon esculentum) in the laboratory and field. J. Chem. Ecol. 22:1767-1781.

27. Ton, J., and Mauch-Mani, B. 2004 . $\beta$-aminobutyric acid-induced resistance against necrotrophic pathogens is based on ABA-dependent priming for callose. Plant J. 38:119-130.

28. Vallad, G. E., and Goodman, R. M. 2004. Systemic acquired resistance and induced systemic resistance in conventional agriculture. Crop Sci. 44:19201934.

29. Van Hulten, M., Pelser, M., Van Loon, L. C., Pieterse, C. M. J., and Ton, J. 2006. Costs and benefits of priming for defense in Arabidopsis. Proc. Natl. Acad. Sci. USA 103:5602-5607.

30. Walters, D. R. 2009. Are plants in the field already induced? Implications for practical disease control. Crop Prot. 28:459-465.

31. Walters, D. R., and Fountaine, J. M. 2009. Practical application of induced resistance to plant diseases: an appraisal of effectiveness under field conditions. J. Agric. Sci. 147:1-13.

32. Walters, D., and Heil, M. 2007. Costs and trade-offs associated with induced resistance. Physiol. Mol. Plant Pathol. 71:3-17.

33. Walters, D. R., Paterson, L., and Havis, N. D. 2010. Control of foliar diseases of spring barley using resistance elicitors. Proc. Crop Prot. North. Br. 2010:91-96.

34. Walters, D. R., Paterson, L., Walsh, D. J., and Havis, N. D. 2009. Priming for plant defense in barley provides benefits only under high disease pressure. Physiol. Mol. Plant Pathol. 73:95-100.

35. Walters, D., Walsh, D., Newton, A., and Lyon, G. 2005. Induced resistance for plant disease control: maximizing the efficacy of resistance elicitors. Phytopathology 95:1368-1373.

36. Zadoks, J. C., Chang, T. T., and Konzak, C. F. 1974. A decimal code for the growth stages of cereals. Weed Res. 14:415-421.

37. Zimmerli, L., Jakab, G., Métraux, J.-P., and Mauch-Mani, B. 2000 Potentiation of pathogen-specific defense mechanisms in Arabidopsis by beta-aminobutyric acid. Proc. Natl. Acad. Sci. USA 97:12920-12925.

38. Zimmerli, L., Métraux, J.-P., and Mauch-Mani, B. 2001. $\beta$-Aminobutyric acid-induced protection of Arabidopsis against the necrotrophic pathogen Botrytis cinerea. Plant Physiol. 126:517-523. 